\title{
HESSIAN FLY, Mayetiola destructor (Say), POPULATIONS IN THE NORTH OF TUNISIA: VIRULENCE, YIELD LOSS ASSESSMENT AND PHENOLOGICAL DATA
}

\author{
Hanem Makni' ${ }^{1}$ Dhia Bouktila2*, Maha Mezghani ${ }^{3}$, and Mohamed Makni ${ }^{3}$
}

\begin{abstract}
Hessian fly, Mayetiola destructor (Say), is a destructive pest of wheat worldwide and an endemic pest in Tunisia. Two natural populations of this insect from the North of Tunisia were evaluated, in the field, for their virulence, based on response developed by bread wheat (Triticum aestivum L.) cultivars carrying $H 3, H 5, H 6, H 7 H 8, H 11, H 13$ and $H 16$ resistance genes. $\mathrm{H} 11, \mathrm{H} 13$ and $\mathrm{H} 16$ showed a high effectiveness against both populations; therefore, their implication in Hessian fly breeding programs would be of interest. The level of infestation, as well as the yield loss, was assessed, based on the percentage of infested plants and variation in growth parameters due to infestation. The percentage of infested plants, over a 2-yr period in Mateur, averaged $18.82 \%$ for durum wheat (Triticum turgidum L. subsp. durum (Desf.) Husn.) and $32.50 \%$ for bread wheat. For the improved durum wheat cv. Karim used as reference, the plant height, number of internodes, number of productive tillers per plant, and 100-seed weight were negatively affected by infestation, while the number of tillers per plant was positively affected. Aiming to update information about the annual number of the fly generations occurring on wheat, we surveyed infestation in Jédéida. At least three Hessian fly generations were detected on bread wheat and durum wheat. Continued regular surveying of Hessian fly populations in terms of virulence, impact on yield and annual generations is required for optimal deployment of resistance genes and integrated management of Hessian fly across all wheat production areas.
\end{abstract}

Key words: Mayetiola destructor, wheat, biotype, generations, integrated pest management.

$\mathrm{H}$ essian fly, Mayetiola destructor Say (Diptera: Cecidomyiidae), is a major pest of wheat worldwide. In Tunisia, numerous outbreaks of this midge have been recorded since 1930 (Pagliano, 1935) and a severe damage on wheat, Triticum spp., has been caused especially in the regions of Jédéida, Mateur, Goubellat, El-Fahs, and Mejez-El-Beb, representing a great part of arable land and meeting more than one half of the nation's wheat production (Miller et al., 1989; Makni et al., 2000).

The most economical and practical means of controlling this insect remains the development of resistant cultivars. The biological interaction between wheat and Hessian fly is highly specific, with a gene-for-gene relationship between resistance genes in wheat and avirulence genes in the insect (Hatchett and Gallun, 1970). Wheat resistance

${ }^{1}$ Faculty of Sciences of Tunis, Laboratory of Molecular Genetics, Immunology and Biotechnology, Campus Universitaire 2092, El Manar Tunis, Tunisia/Higher Institute of Animation for Youth and Culture of Bir-El-Bey, Tunisia.

${ }^{2}$ Faculty of Sciences of Tunis, Laboratory of Molecular Genetics, Immunology and Biotechnology, Tunisia/Higher Institute of Biotechnology of Béja, Tunisia.

*Corresponding author(dhia_bouktila2000@yahoo.fr).

${ }^{3}$ Faculty of Sciences of Tunis, Laboratory of Molecular Genetics, Immunology and Biotechnology, Campus Universitaire 2092, El Manar Tunis, Tunisia.

Received: 1 December 2010.

Accepted: 21 June 2011. to $M$. destructor attack is conditioned mostly by dominant alleles at single locus ( $H$ genes), whereas virulence against wheat is determined by recessive alleles at single locus in $M$. destructor (avr genes). To date, 33 resistance genes have been identified (H1-H32 and Hdic) (Liu et al., 2005). In USA, 16 biotypes (designated Great Plains and $\mathrm{A}$ to $\mathrm{O}$ ) have been identified in the laboratory, on the basis of their response (virulence or avirulence) to four common wheat cultivars carrying the $\mathrm{H3}, \mathrm{H} 5, \mathrm{H} 6$ or $\mathrm{H7H}$ resistance genes (Gallun, 1977). Virulent insect biotypes occur in nature as a result of selection from the population in response to exposure to resistant cultivars. However, Hessian fly virulence has been demonstrated even to some resistance genes that have not been deployed in wheat cultivars in USA (Ratcliffe et al., 1994). Therefore, testing the available genes against as many current populations of Hessian fly as possible is necessary, which would prevent the release of wheat cultivars with ineffective sources of resistance.

Surveying the annual number of Hessian fly generations could be of great help in order to establish an integrated pest management strategy, taking into account fly-free dates for planting cereals (Hodgson, 2009). The Hessian fly life cycle was described by several authors (Painter, 1951; Ratcliffe and Hatchett, 1997; Royer and Giles, 2009). In brief, adult females of $M$. destructor live 1 to $2 \mathrm{~d}$ and lay 250 to 300 reddish-colored eggs on the upper side 
of cereal leaves. First-instar larvae hatch from the eggs after 3 to $10 \mathrm{~d}$. They crawl down to their preferred feeding site, at the base of a leaf. The white second-instar larvae (L2) crawl down to the crown of the plant, were they are transformed into third-instar larvae (L3). The last stage of the life cycle is spent inside a protective structure called the flaxseed. If weather conditions are favorable, the Hessian fly adults will emerge and start a new generation. If not, Hessian flies remain as larvae inside the flaxseed until the weather moderates. According to Painter (1951), the entire life cycle duration is comprised between 20 and $61 \mathrm{~d}$. The available data on the number of Hessian fly generations in Tunisia are quite old. Pagliano (1935) reported that cereals in Tunisia can harbour up to five Hessian fly generations a year, from October/November to May/June; therefore, it's highly recommended to update knowledge about the annual rhythm of infestation.

In order to enhance the efforts towards the development of a Hessian fly integrated controlling strategy, the main objectives of this research were: (i) to test the effectiveness of wheat cultivars carrying different Hessian fly resistance genes against the insect populations; (ii) assess yield losses caused to wheat by the fly genotypes; and (iii) acquire recent data on the annual number of generations developed by this fly on wheat, in Tunisia.

\section{MATERIALS AND METHODS}

\section{Virulence to resistance genes}

In order to investigate virulence of Hessian fly populations in northern Tunisia, we have screened seven bread wheat cultivars expressing $H$ genes. These cultivars were Monon
(H3), Ribeiro (H5), Knox 62 (H6), Seneca (H7H8), IN657C1 (H11), KSH 8998 (H13) and RJ91 (H16). The wheat cv. Newton was used as susceptible control. All these cultivars originated from the American Uniform Hessian Fly Nursery (UHFN, National Small Grain Collection, USDA-ARS, USA) and were grown in the Centre National de Recherche Scientifique (CNRS), Gif-sur-Ivette, France. They were evaluated for resistance during two consecutive years (2008 and 2009) at the locations of Mateur $\left(37^{\circ} 02^{\prime}\right.$ $\left.\mathrm{N} ; 9^{\circ} 39^{\prime} \mathrm{E}\right)$ and Jédéida $\left(36^{\circ} 51^{\prime} \mathrm{N}\right.$; $\left.9^{\circ} 55^{\prime} \mathrm{E}\right)$ in the North of Tunisia. Each experiment consisted in three randomized blocks, with 30 seeds sown per cultivar and block; and no insecticide or fertilizer treatment were applied. Plants that were stunted and had a dark green color were considered as susceptible, those that had normal growth, with a light green colour were considered as resistant. Resistance was further confirmed by the presence of dead larvae at the bases of stems (Gallun, 1977). Data for each Hessian fly population were calculated as percentages of resistant plants.

\section{Assessment of infestation level and yield loss}

Two field assays were conducted during two consecutive years (2008 and 2009) at Mateur, to determine the intensity of Hessian fly infestation, compare the infestations on durum wheat to those on bread wheat and observe annual variation in the infestation levels. Seventeen durum wheat and four bread wheat genotypes were used in this investigation (Table 1). Each assay was free from insecticide or fertilizer treatments and contained three randomized blocks with 30 seeds sown per cultivar and block. The intensity of infestation was evaluated based on the percentage of infested plants of each tested cultivar.

Table 1. List of cereal genotypes used to assess intensity of infestation, their pedigree (when available), their breeding institute (in case of inbred cultivars) or region of origin and the year of their introduction or release (Medini et al., 2005; Déghaïes et al., 2007).

\begin{tabular}{|c|c|c|c|c|c|}
\hline Species & & Genotype & Pedigree & $\begin{array}{l}\text { Breeding insti- } \\
\text { tute or region of } \\
\text { origin }\end{array}$ & $\begin{array}{l}\text { Year of } \\
\text { introduction }\end{array}$ \\
\hline \multirow{17}{*}{$\begin{array}{l}\text { Triticum turgidum L. subsp. } \\
\text { durum (Desf.) Husn. (durum wheat) }\end{array}$} & \multirow[t]{4}{*}{ Modern cultivars } & Karim & JO'S'/AA'S'//FG‘S' & CIMMYT & 1980 \\
\hline & & Razzak & DMx69-331/Karim & INRAT & 1987 \\
\hline & & Ben Béchir & Galo469/3/JO‘S’//61-130/LDS & CIMMYT & 1978 \\
\hline & & INRAT 69 & $=$ DS58-25 = Kyperounda $\times$ Mahmoudi 981 & INRAT & 1969 \\
\hline & \multirow[t]{13}{*}{ Old cultivars } & Real Forte & - & Sicilia (Italy) & 1907 \\
\hline & & Souri & - & Foreign & \\
\hline & & Tunis & - & & \\
\hline & & Sébéi & - & Indigenous genotype & 1907 \\
\hline & & Médéa & - & Algeria & 1893 \\
\hline & & Mekki & - & Morocco & 1893 \\
\hline & & Bidi & - & Algeria & 1907 \\
\hline & & Agili & - & Morocco & 1913 \\
\hline & & Azizi & - & Indigenous genotype & 1893 \\
\hline & & Jénah Khottifa & - & Indigenous genotype & 1907 \\
\hline & & Mahmoudi & - & Algeria & 1893 \\
\hline & & Hamira & - & Indigenous genotype & \\
\hline & & Biskri & - & Algeria & 1908 \\
\hline \multirow[t]{6}{*}{ Triticum aestivum L. (bread wheat) } & & Byrsa & Gallo/Cuckoo“S”//Kavkaz/SuperX & CIMMYT and INRAT & 1982 \\
\hline & & & $\begin{array}{l}\text { CM34630-D-3M-3Y-1M-1Y-0M-1BJ-4BJ- } \\
\text { 13BJ-4BJ-0BJ }\end{array}$ & & \\
\hline & & \multirow[t]{2}{*}{ Tanit } & Tzpp/Paloma//SC & & \\
\hline & & & $\begin{array}{l}\text { CM5287-J-1Y-2M-2Y-3M-0Y-4BJ-30BJ- } \\
\text { 6BJ-0BJ }\end{array}$ & CIMMYT & 1974 \\
\hline & & Florence-Aurore & - & - & - \\
\hline & & Cultivar 2123 & - & - & - \\
\hline
\end{tabular}

CIMMYT: International Maize and Wheat Improvement Centre; INRAT: Institut National de Recherches Agronomiques de Tunisie. 
The yield loss was assessed, in 2009, for the durum wheat line 'Karim', widely used at the commercial scale in Tunisia, using five growth parameters: plant height, number of internodes, number of tillers per plant, number of productive tillers per plant, and 100-seed weight. The obtained results for each of the five parameters were submitted to a ANOVA, using the SAS software (VAX version 6.08, SAS Institute, Cary, North Carolina, USA).

\section{Determination of the annual number of Hessian fly life cycles}

Regular surveys (2-3 per month) were conducted, from November 2008 to May 2009, in two private fields cultivated, respectively, with durum wheat ('Karim') and bread wheat ('Salambo') and located in the area of Jédéida. At each survey, plants were observed after being collected at random, every 10 steps, following multiple transects. At least 100 plants of each field were examined, in each survey. Notes were taken on the infestation of durum wheat and bread wheat. When plants from a given species were infested, the percentage of infested plants and the larval stage of insects were determined.

\section{RESULTS AND DISCUSSION}

\section{Virulence to resistance genes}

Results of tests with Hessian fly populations and wheat cultivars are summarized in Table 2. 'Newton' was susceptible in all assays conducted with the two studied populations. In Mateur location, results of the 2008 and 2009 field assays were correlated with a 0.999 Pearson correlation coefficient. 'Monon' (H3) and 'Knox 62' (H6) showed a resistance level under $50 \%$. Thus, both cultivars can be rated as weakly resistant. 'Seneca' $(\mathrm{H} 7 \mathrm{H} 8)$ resisted at a rate comprised in the interval $50 \%$ $75 \%$ and could be classified as moderately resistant. The highest levels of resistance $(>75 \%)$ were expressed by 'Ribeiro' (H5), 'IN657C1' (H11), 'KSH8998' (H13) and 'RJ91' (H16). In Jédéida location, results of the two field assays were strongly correlated, with a 0.975 Pearson correlation coefficient, revealing that 'Ribeiro' (H5) was weakly resistant (<50\% resistant plants); 'Knox 62' (H6)

Table 2. Response of seven wheat cultivars carrying $\mathrm{H3}, \mathrm{H} 5, \mathrm{H6}, \mathrm{H} 7 \mathrm{H} 8$, $\mathrm{H} 11, \mathrm{H} 13$ and $\mathrm{H} 16$ resistance genes to Hessian fly populations from Mateur and Jédéida locations in the North of Tunisia.

\begin{tabular}{|c|c|c|c|c|}
\hline \multirow{3}{*}{$\begin{array}{l}\text { Wheat cultivar } \\
\text { (resistance gene) }\end{array}$} & \multicolumn{4}{|c|}{ Resistant plants } \\
\hline & \multicolumn{2}{|c|}{ Mateur } & \multicolumn{2}{|c|}{ Jédéida } \\
\hline & 2008 & 2009 & 2008 & 2009 \\
\hline Newton (none) ${ }^{*}$ & $0.0 \pm 0.0$ & $0.0 \pm 0.0$ & $0.0 \pm 0.0$ & $0.0 \pm 0.0$ \\
\hline Monon $(H 3)$ & $21.0 \pm 2.3$ & $23.0 \pm 7.7$ & $76.0 \pm 6.6$ & $77.1 \pm 2.0$ \\
\hline Ribeiro (H5) & $95.0 \pm 1.5$ & $98.0 \pm 1.0$ & $30.0 \pm 1.2$ & $45.6 \pm 5.1$ \\
\hline Knox $62(H 6)$ & $31.0 \pm 4.3$ & $31.2 \pm 2.1$ & $42.0 \pm 1.3$ & $55.5 \pm 1.1$ \\
\hline Seneca $(H 7 H 8)$ & $74.0 \pm 2.4$ & $75.0 \pm 2.4$ & $58.3 \pm 0.4$ & $65.3 \pm 0.9$ \\
\hline IN $657 \mathrm{C} 1(H 11)$ & $94.0 \pm 2.6$ & $94.0 \pm 4.6$ & $94.7 \pm 0.0$ & $90.1 \pm 2.2$ \\
\hline KSH 8998 (H13) & $93.0 \pm 3.5$ & $93.0 \pm 5.5$ & $100 \pm 0.0$ & $91.0 \pm 1.1$ \\
\hline RJ91 (H16) & $90.0 \pm 4.3$ & $91.0 \pm 2.3$ & $87.5 \pm 1.0$ & $87.0 \pm 2.5$ \\
\hline
\end{tabular}

* Susceptible cv. Newton was used as control. was weakly to moderately resistant; 'Monon' (H3) and 'Seneca' $(H 7 H 8)$ were moderately resistant $(50 \%-75 \%)$; 'IN657C1' (H11), 'KSH8998' (H13) and 'RJ91' (H16) were highly resistant (over $75 \%$ resistant plants).

It can be inferred that 'IN657C1' (H11), 'KSH8998' (H13) and 'RJ91' (H16) were highly resistant to both Mateur and Jédéida populations, 'Knox 62' (HO) was weakly resistant and 'Seneca' (H7H8) was moderately resistant. As for 'Monon' (H3) and 'Ribeiro' (H5), they varied in response depending on the fly population. This fact could be triggered by a certain extent of divergence between the two studied populations, in term of eventual biotype mixture components. The H5 gene was highly resistant to the Hessian fly population from Mateur, but displayed only a restricted level of resistance to the fly population from Jédéida. This fact could be a consequence of the $H 5$ susceptibility to high temperatures, as reported by Sosa (1979). Indeed, except for H5, Hessian fly resistance genes expression is not influenced by temperatures (El Bouhssini et al., 1999). To the best of our knowledge, the present study is the first one where H16 is reported as a promising source of resistance to Hessian fly populations. Previous reports from North Africa indicated that H11 and $H 13$ genes were resistant to Tunisian Hessian fly (Bouktila et al., 2005) and H5, H7H8, H11, H13, H14, $\mathrm{H} 15, \mathrm{H} 21, \mathrm{H} 22, \mathrm{H} 23, \mathrm{H} 25$ and $\mathrm{H} 26$ genes resistant to Moroccan Hessian fly, in several different locations where tests were conducted (El Bouhssini et al., 1999; Lhaloui et al., 2000). In West Asia, two resistance genes, H25 and $H 26$, have recently been reported to be effective against Hessian fly populations from Syria (El Bouhssini et al., 2009). Besides, a recent virulence analysis reported that H13, H21, H25, H26 and Hdic were the most effective genes against three Hessian fly populations, namely Texas, Oklahoma and Kansas, in USA (Chen et al., 2009).

\section{Infestation level and yield loss assessment}

The percentage of infested tillers of the studied wheat lines averaged, over the 2-yr period of the test, 18.82 for durum wheat and 32.50 for bread wheat (Table 3). 'Ben Béchir', 'INRAT69', 'Souri', 'Tunis', 'Sébéi', 'Médéa', 'Mekki', 'Bidi' durum wheats and 'Byrsa', 'Florence aurore' bread wheats were not infested. By surveying of Hessian fly, in Morocco, over a 4-yr period, Lhaloui et al. (1992) found that infestations of durum wheat and bread wheat were equivalent. In our study, bread wheat varieties were infested more heavily than those of durum wheat. This could be explained by the limited number of bread wheat varieties used in this study.

The analysis of yield parameters (Table 4) showed that the plant height, number of internodes, number of tillers per plant, number of productive tillers per plant and 100-seed weight were significantly affected by infestation. On average, infested plants are shorter, have fewer internodes and productive tillers and lighter grains than non infested plants; that's these growth parameters 
Table 3. Percentage of Hessian fly-infested plants for 21 tested genotypes of durum and bread wheat, estimated over $2 \mathrm{yr}$ in the region of Mateur.

\begin{tabular}{|c|c|c|c|c|}
\hline \multirow[b]{2}{*}{ Crop } & \multicolumn{4}{|c|}{ Intensity of infestation } \\
\hline & Variety & $2008^{*}$ & $2009^{*}$ & Mean \\
\hline & & fested $t$ & s $(\%)$ & \\
\hline \multirow{18}{*}{$\begin{array}{l}\text { Triticum turgidum L. } \\
\text { subsp. durum (Desf.) } \\
\text { Husn. (durum wheat) }\end{array}$} & Karim & 38 & 32 & 35 \\
\hline & Razzak & 25 & 15 & 20 \\
\hline & Ben Béchir & 0 & 0 & 0 \\
\hline & INRAT 69 & 0 & 0 & 0 \\
\hline & Real Forte & 41 & 39 & 4 \\
\hline & Souri & 0 & 0 & 0 \\
\hline & Tunis & 0 & 0 & 0 \\
\hline & Sébéi & 0 & 0 & 0 \\
\hline & Médéa & 0 & 0 & 0 \\
\hline & Mekki & 0 & 0 & 0 \\
\hline & Bidi & 0 & 0 & 0 \\
\hline & Agili & 52 & 58 & 55 \\
\hline & Azizi & 30 & 30 & 30 \\
\hline & Jénah Khottifa & 31 & 39 & 35 \\
\hline & Mahmoudi & 35 & 35 & 35 \\
\hline & Hamira & 29 & 41 & 35 \\
\hline & Biskri & 30 & 40 & 35 \\
\hline & Average & 18.29 & 19.35 & $18.82 \pm 1.59$ \\
\hline \multirow{5}{*}{$\begin{array}{l}\text { Triticum aestivum } \mathrm{L} \text {. } \\
\text { (bread wheat) }\end{array}$} & Byrsa & 0 & 0 & 0 \\
\hline & Tanit & 60 & 70 & 65 \\
\hline & Florence-Aurore & 0 & 0 & 0 \\
\hline & Cultivar 2123 & 66 & 64 & 65 \\
\hline & Average & 31.5 & 33.5 & $32.50 \pm 1.50$ \\
\hline
\end{tabular}

"The values correspond to averages of three replicates.

Table 4. Effect of infestation on five yield parameters, estimated on durum wheat cv. Karim, in 2009.

\begin{tabular}{lcc}
\hline Growth parameters & $\begin{array}{c}\text { Non-infested } \\
\text { plants }\end{array}$ & Infested plants \\
\hline Plant height, cm & $70.10 \mathrm{a}(614)$ & $53.14 \mathrm{~b}(658)$ \\
Number of internodes & $5.52 \mathrm{a}(614)$ & $5.50 \mathrm{~b}(658)$ \\
Number of tillers per plant & $1.57 \mathrm{a}(614)$ & $3.42 \mathrm{~b}(658)$ \\
Number of productive tillers per plant & $0.99 \mathrm{a}(614)$ & $0.96 \mathrm{~b}(658)$ \\
100-seed weight, g & $4.20 \mathrm{a}(614)$ & $3.38 \mathrm{~b}(658)$ \\
\hline
\end{tabular}

Percentages followed by two different letters, within each row, are significantly different (LSD: $\mathrm{p}<0.01$ )

Values in parenthesis: Number of observations. The values correspond to averages of three replicates.

were diminished due to infestation. However, the number of tillers was higher in infested plants. Both decrease/ increase of growth parameters could be associated with the defence mechanisms developed by the wheat plant in order to counter insect attack. In fact, decreasing plant height, number of internodes, number of productive tillers per plant and 100-seed weight would result from antinutrition reactions (e.g. limiting food supply, reducing nutrient value, death of cells at the infection site), that are developed by the host plant during infestation to prevent further spread of the insect larvae (Chen, 2008). On the other hand, an increase of number of tillers per plant may be interpreted as a modification of the local environment of the attacking insect (Harris et al., 2006; Zhu et al., 2008).

\section{Annual number of Hessian fly life cycles}

The results of the investigation (Table 5) indicated the occurrence of at least three Hessian fly generations on bread or durum wheat, namely, fall, winter, and spring generations. Further, the reproduction of Hessian fly on both wheat species seems synchronized. Larvae resulting of the last generation probably remain at the flaxseed stage, during the following summer.
Table 5. Survey of Hessian fly infestation occurrence on durum wheat and bread wheat in Jédéida (North of Tunisia), during the 2008-2009 season.

\begin{tabular}{|c|c|c|}
\hline & $\begin{array}{l}\text { Durum wheat, Triticum } \\
\text { turgidum subsp. durum }\end{array}$ & $\begin{array}{l}\text { Bread wheat, } \\
\text { Triticum aestivum }\end{array}$ \\
\hline & Larval stage (if any) & Larval stage (if any) \\
\hline November 2008 & Flaxseed & Flaxseed \\
\hline December 2008 & - & - \\
\hline January 2009 & Third-instar larvae + Flaxseed & Third-instar larvae + Flaxseed \\
\hline February 2009 & - & - \\
\hline March 2009 & - & - \\
\hline April 2009 & Second-instar larvae & Second-instar larvae \\
\hline May 2009 & Flaxseed & Flaxseed \\
\hline
\end{tabular}

In a similar survey of Hessian fly infestation, in the region of Rabat in Morocco, Durand (1967) reported three Hessian fly generations on wheat. In Europe, several reports have indicated the occurrence of 2-3 generations of Hessian fly on wheat, with a chronological difference: adults of the first generation usually emerge in April and those of subsequent generations may be active throughout summer and fall. Therefore, we think that the generation of Hessian fly occurring in summer in Europe is absent in North Africa, as a consequence of prolonged dry and hot weather causing mortality of puparia. This generation is replaced by a winter generation during the warm winter of North Africa. The relationship between Hessian fly chronology, the geographical location and the prevailing climatic conditions is documented in Wellso (1991). Although phenological data on Hessian fly in the North of Tunisia could be interesting in fighting Hessian fly through the recommendation of safe dates for planting cereals, we think that they should be generalized into an integrative look, taking into account variation in climate between years/regions, as well as the agricultural landscape, i.e. the existence/absence of some grasses (e.g. Bromus), which enhance the insect reproduction by hosting relay generations.

\section{CONCLUSIONS}

Because of their high effectiveness against Hessian fly in Jédéida and Mateur, we conclude that H11, H13 and H16 should be the first choice for use within a wheat breeding strategy, consisting in the sequential deployment of single resistance genes in the wheat-growing areas of North Tunisia. Nevertheless, with a fairly high number of generations per year (three), there is a large amount of genetic variability among and within Hessian fly populations which is likely to enhance selection of new genotypes capable of overcoming these resistance genes. Therefore, it is important to stay continuously alerted and ahead of the development of new pest genotypes in order to develop an appropriate gene deployment strategy based on long-term integration of data on insect virulence and phenology.

\section{ACKNOWLEDGEMENTS}

This work is dedicated to the memory of late Prof. Mohamed Marrakchi. Financial support of the Tunisian 
Ministry of Higher Education and Scientific Research is gratefully acknowledged. We address special thanks to Professor Abderrazzak Daaloul for his constant support.

Poblaciones de mosca de Hess, Mayetiola destructor (Say), en el Norte de Túnez: Virulencia, evaluación de pérdida de producción y datos fenológicos. La mosca de Hess, Mayetiola destructor (Say), es una plaga mundial destructiva del trigo y endémica en Túnez. Se evaluaron dos poblaciones naturales de este insecto desde el Norte de Túnez, en el campo, por su virulencia, basado en la respuesta desarrollada por cultivares de trigo panadero (Triticum aestivum L.) portando los genes de resistencia H3, H5, H6, H7H8, H11, H13 y H16. H11, H13 and $H 16$ mostraron una alta efectividad contra ambas poblaciones; por lo tanto, su implicancia en programas de producción de mosca de Hess podría ser de interés. Se evaluaron el nivel de infestación y la pérdida de rendimiento, basado en el porcentaje de plantas infestadas y variación en parámetros de crecimiento debidos a infestación. El porcentaje de plantas infestadas, en un período de 2 años en Mateur, promedió 18,82\% para trigo candeal (Triticum turgidum L. subsp. durum (Desf.) Husn.) y 32,50\% para trigo panadero. Para el trigo candeal mejorado cv. Karim usado como referencia, altura de planta, número de entrenudos, número de cañas productivas por planta, y peso de 100 semillas fueron negativamente afectados por infestación, mientras el número de cañas por planta fue positivamente afectado. Con el fin de actualizar la información sobre el número anual de las generaciones de mosca en trigo, investigamos infestación en Jédeida. Al menos tres generaciones de mosca de Hess se detectaron en trigo panadero y candeal. Se requieren ensayos regulares de virulencia, impacto en rendimiento, y generaciones anuales de poblaciones de mosca de Hess para un óptimo despliegue de genes de resistencia y manejo integrado de la mosca por todas las áreas productoras de trigo.

Palabras clave: Mayetiola destructor, trigo, biotipo, generaciones, manejo integrado de plagas.

\section{LITERATURE CITED}

Bouktila, D., M. Mezghani, M. Marrakchi, and H. Makni. 2005. Identification of wheat sources resistant to Hessian fly, Mayetiola destructor (Diptera: Cecidomyiidae) in Tunisia. International Journal of Agriculture and Biology 7:799-803.

Chen, M.S. 2008. Inducible direct plant defense against insect herbivores: A review. Insect Science 15:101-114.

Chen, M.S., E. Echegaray, R.J. Whiworth, H. Wang, P.E. Sloderbeck, A. Knutson et al. 2009. Virulence analysis of Hessian fly (Mayetiola destructor) populations from Texas, Oklahoma, and Kansas. Journal of Economic Entomology 102:774-780.

Déghaïes, M., M. Kouki, M.S. Gharbi, and M. El-Faleh. 2007. Les variétés de céréales cultivées en Tunisie. 250 p. Institution of Scientific Agricultural Research and Education-National Institute of Agricultural Research of Tunisia, Tunis, Tunisia.

Durand, Y. 1967. Observation sur le cycle évolutif des Mayetiola vivant sur orge et blé, au Maroc. Al-Awamia 24:1-15.

El Bouhssini M., M. Chen, S. Lhaloui, G. Zharmukhamedova, and F. Rihaoui. 2009. Virulence of Hessian fly (Diptera: Cecidomyiidae) in the Fertile Crescent. Journal of Applied Entomology 133:381-385.
El Bouhssini, M., J.H. Hatchett, and J.E. Wilde. 1999. Hessian fly (Diptera: Cecidomyiidae) larval survival as affected by wheat resistance alleles, temperature and larval density. Journal of Agricultural Urban Entomology 16:245-254.

Gallun, R.L. 1977. Genetic basis of Hessian fly epidemics. Annals of the New York Academy of Sciences 287:223-229.

Harris, M.O., T.P. Freeman, O. Rohfritsch, K.G. Anderson, S.A. Payne, and J.A. Moore. 2006. Virulent Hessian fly (Diptera: Cecidomyiidae) larvae induce a nutritive tissue during compatible interactions with wheat. Annals of the Entomological Society of America 99:305-316.

Hatchett, J.H., and R.L. Gallun. 1970. Genetics of the ability of the Hessian fly, Mayetiola destructor (Say), to survive on wheat having different genes for resistance. Annals of the Entomological Society of America 63:1400-1407.

Hodgson, E. 2009. Approaching Hessian fly-free dates in Iowa. Integrated Crop Management News. Available at http://www. extension.iastate.edu/CropNews/2009/0915hodgson.htm (accessed June 2011).

Lhaloui, S., M. El Bouhssini, N. Nsarellah, M.M. Nachit, and A. Amri. 2000. Biotic stress limiting durum wheat production in Morocco-Hessian fly and the Russian wheat aphid: Surveys, loss assessment and identification of sources of resistance. Options Méditerranéennes, Series A 40:373-379.

Lhaloui, S., L. Buschman, M. El Bouhssini, K. Starks, D.L. Keith, and K. El Houssaini. 1992. Control of Mayetiola species (Diptera: Cecidomyiidae) with carbofuran in bread wheat, durum wheat, and barley, with yield loss assessment and its economic analysis. Al-Awamia 77:55-73

Liu, X.M., G.L. Brown-Guedira, J.H. Hatchett, J.O. Owuoche, and M.S.Chen. 2005. Genetic characterization and molecular mapping of a Hessian fly resistance gene transferred from T. turgidum ssp. dicoccum to common wheat. Theoretical and Applied Genetics 111:1308-1315.

Makni, H., M. Sellami, M. Marrakchi, and N. Pasteur. 2000. Structure génétique des cécidomyies des céréales en Tunisie. Genetics Selection Evolution 32:577-588.

Medini, M., S. Hamza, A. Rebai, and M. Baum. 2005. Analysis of genetic diversity in Tunisian durum wheat cultivars and related wild species by SSR and AFLP markers. Genetic Resources and Crop Evolution 52:21-31.

Miller, R.H., A. Kamel, S. Lhaloui, and M. El Bouhssini. 1989. Survey of Hessian fly in North Tunisia. Rachis 8:27-28.

Pagliano, T.H. 1935. La cécidomyie destructive Mayetiola destructor (Say). p. 341-361. In Service Botanique et Agronomique de Tunisie (ed.) Les parasites animaux des céréales. Tunis, Tunisia.

Painter, R.H. 1951. Insect resistance in crop plants. 200 p. The Macmillan Company, New York, USA.

Ratcliffe, R.H., and J.H. Hatchett. 1997. Biology and genetics of the Hessian fly and resistance in wheat. p. 47-56. In Bondari, K. (ed.) New developments in entomology. Research Singpost, Trivandram, India.

Ratcliffe, R.H., G.G. Safranski, F.L. Patterson, H.W. Ohm, and P.L. Taylor. 1994. Biotype status of Hessian fly (Diptera: Cecidomyiidae) from the eastern United States and their response to 14 Hessian fly resistance genes. Journal of Economic Entomology 87:1113-1121

Royer, T.A., and K.L. Giles. 2009. Plan to manage Hessian fly. Pest e-alerts 8(23). Available at http://entoplp.okstate.edu/Pddl/ (accessed January 2010).

Sosa, J.R. 1979. Hessian fly: resistance of wheat, as affected by temperature and duration of exposure. Environmental Entomology 8:280-281.

Wellso, S.G. 1991. Aestivation and phenology of the Hessian fly (Diptera: Cecidomyiidae) in Indiana. Environmental Entomology 20:795-801.

Zhu, L., X.M. Liu, X. Liu, R. Jeannotte, J.C. Reese, M. Harris, et al. 2008. Hessian fly (Mayetiola destructor) attack causes dramatic shift in carbon/nitrogen metabolism in wheat. Molecular PlantMicrobe Interaction 21:70-78. 